\title{
THE ROLE OF BROADCASTING AGENCY TO BUILD THE LEGAL COMPLIANCE OF SOCIETY
}

\section{Lilik Rukitasari $^{1}$, Irwansyah ${ }^{2}$}

${ }^{1}$ Faculty of Law Trunajaya University

Jl. Tekwondo No 55, Bontang, Kalimantan Timur, Indonesia

Telp./Fax: + 62-548-3035920 E-mail: rukitasari@gmail.com

${ }^{2}$ Faculty of Law Hasanuddin University

Jl. Perintis Kemerdekaan Km. 10, Tamalanrea, Makassar, Sulawesi Selatan, Indonesia

Telp./Fax: +62-411-587219 E-mail: irwansyahrawydharma@yahoo.com

Submitted: May 19, 2016; Reviewed: May 22, 2016; Accepted: Jun 07, 2016

\begin{abstract}
Broadcasting has become part of peoples' lives needs for information, entertainment and education. Broadcasting agency as mass communication media play a role to shape the behavior of political, social, and economic in every society, in order to establish the public legal compliance through broadcasting activities that are counseling and law clarification, it takes effective communication media so that the target is expected to be achieved through increased the quality broadcast programs and attractive containing understanding and knowledge about the law will be able to increase publics' consciousness and legal compliance. This study using sociological-juridical approach by analyzing the empirical data in order to understand the social and legal responsibilities and functions of broadcasting as a mass communication media is effective in disseminating the law and the formation of values, the result of study drawn through the broadcast media were able to create a culture norms, it means the function of media is not only as a transmitter of information to disseminate the law to the public but also it can have the effect of influencing and encouraging the change of behavior towards the law-abiding.
\end{abstract}

Keywords: Broadcasting Agency, Law Compliance, Society

\section{INTRODUCTION}

The second amendment of the constitution 1945 to result a change in concerned article with the human rights and includes changes to article $28 \mathrm{~F}$ that "everyone has the right to communicate and obtain information to develop personal and its social, as well as the right to seek, obtain, possess, store, process and disseminate information by using all available channels".

Independence to express an opinion, disseminate, and obtain information, sourced from peoples' sovereignty and the human rights in the 
life of social, civic and democratic state. Independence or freedom in broadcasting should be guaranteed by the state. In this regard, the Constitution of the Republic of Indonesia 1945 recognizes, guarantees and protects it. In order to safeguard national integrity, strengthening the values of religion, truth, justice, morals, and ethics, as well as to promote the general welfare, and educating the nation, then the implementation of freedom must be implemented responsibly, harmony and balance between freedom and equality to use right.

Basically, the arrangement of media are governed by the view that the media was using the public domain or not, which means there are two kinds of regulation, i.e media that use the public domain or not. For media that not use the public domain, for example, books, newspapers, magazines, and movies. In principle, state intervention in the media is very small. The arrangement is based on the principle of self-regulatory, selfregulation while using the public domain that free to air, and terrestrial.
The regulation to the radio and television is highly regulated.

The reason why the regulation of electronic media use the public domain is conducted strictly due to; first, because the media use the public domain, free to air. The spectrum of radio waves in the form of a frequency used by broadcast media is publicly owned, which should be used and utilized for the widest possible public welfare and the use of these frequencies are used and borrowed by investors and television owners. Second, this frequency is limited (scarcity theory). When later the digital technology began to be used, the number of broadcasting can and will be more, but remain limited. Third, television program can be entered and penetrated the living room, our bedroom simultaneously and extends, without we invite (pervasive presence theory). ${ }^{1}$

Act No 32 on 2002 concern Broadcasting, focuses on public participation in any policies made countries in the field of broadcasting and rests on the social commitment,

\footnotetext{
${ }^{1}$ Amir Effendi Siregar, Jurnal media kasus Silet: Kemenangan bagi Publik, KPI, Jakarta, 2012, page 10
} 
which is trying to accommodate the public in the life of broadcasting. This is an excess of reformation in this country. Where the people are given a place for participation in any policy made by the state, especially regarding policies that will affect them directly.

The development of broadcasting is directed at the creation of quality, dignified broadcast, able to penetrate and reflect the aspirations of diverse people, to increase the deterrent power of society to the adverse effects of foreign cultural values. ${ }^{2}$

In the field of political and national life is also realized the importance of the media as the fourth pillar of democracy, the role of media is so important in creating a democratic life. In the perspective of political, social control is intended to oversee the social and political behavior of society, especially watch dog. The transparency of public accountability for officials and media for peoples' opinions. That is why the press is one of the 4 (four) pillars of democracy

\footnotetext{
${ }^{2}$ See, Explanation the Constituion No 32 of 2002 concerns Broadcasting
}

(the fourth estate): executive, legislative, judiciary and press. ${ }^{3}$

The press, both print and electronic is instrumental in the social order that is vital for improving the quality of life of its citizens. It is also a reflection of the identity of the community in addition to its function as a media of information and communication, because what is stated in the press is a pulse of community life where the press is located. ${ }^{4}$

Indeed, broadcasting is organized with the aim to strengthen the national integrity, maintain character and national identity of faith and piety, educating the nation to promote the general welfare, in order to build a society that is independent, democratic, fair and well-being as well as grow the Indonesian broadcasting industry. ${ }^{5}$

But now, function and direction of our broadcasting are still do not suitable as mandated by broadcasting act. In particular, the influence of television media is very large to the

\footnotetext{
${ }^{3}$ Asep Saefullah Muhtadi, Jurnalistik Pendekatan Teori dan Praktek, Jakarta: Logos, 1999. page. 48

${ }^{4}$ Samsul Wahidin, Hukum Pers, Pustaka Pelajar, Yogyakarta, 2006, page. 3

${ }^{5}$ Media watch Jurnal Pemantau Media Edisi no. 67/15 May - 15 June 2008, page 23
} 
establishment of community mental, and not infrequently it is precisely in the content of broadcasts influence even creating public opinion. ${ }^{6}$

In modern society, it is experienced a premise of the Marxist theory about media positions in the system of capitalism, it is stated "mass media is a governing class" because it serves as a tool of subjugation and coercion consensus by groups that are economically and politically dominant. $^{7}$ Eventually, the history shows that mass media reached the peak of development as key agency in modern society. The mass media were able to self-representative as a major public space and determine the dynamics of social, politics, and culture at local and global levels. ${ }^{8}$

This paper seeks to illustrate how broadcast media are an effective means in disseminating the rules of law in society, this study using sociologicaljuridical approach by analyzing the empirical data in order to understand the social and legal responsibilities and

\footnotetext{
${ }^{6}$ Jurnal Penyiaran Kita Edisi November December 2015, page 21

7 Agus Sudibyo, Jurnal Ekonomi Politik Media Penyiaran, LKiS Yogyakarta, 2004, page 1

${ }^{8}$ Ibid, page 2
}

functions of broadcasting instituion as a media of mass communication is effective in socialize law and the formation of values that can encourage the behavioral change towards the lawabiding.

\section{DISCUSSIONS AND ANALYSIS}

The Role of Broadcasting Agency as an Effort to Build the Legal

\section{Compliance of Society}

The social responsibility theory, media adhering to human knowledge. With his ratio, humans can distinguish between things that are useful, good and which ones are not good and not helpful and not good. If the man is working in the press area then he can tell which is good and which is not good, so all the communication messages and information released by the press accountable to the fullest. ${ }^{9}$

The social responsibility theory has a core idea: anyone who enjoys freedom also has certain responsibilities to society. This theory emerged because the theory of libertarian considered being too

\footnotetext{
${ }^{9}$ Soemarno, Perbandingan Sistem Komunikasi, Jakarta, 2004, page.5
} 
concerned with freedom. ${ }^{10}$ The main principle of social responsibility theory as follows:

a. Media should accept and fulfill certain obligations to society.

b. The obligations is accomplished by establishing high standards or professionalism of information, truth, accuracy, objectivity and balance.

c. In accepting and implementing these obligations, the media should be able to organize themselves within the framework of existing laws and institutions.

d. Media should avoid anything that might give rise to crime, damage, or lack of public order or insult to ethnic or religious minorities.

e. The media as a whole should be pluralist and reflect to the people, by providing equal opportunities to express different points of view and the right to respond.

f. Society and the public, based on the principles of the former, have the right to expect a high standard of achievement and intervention

\footnotetext{
${ }^{10}$ William L. Rivers, Media Massa \& Masyarakat Modern (terjemahan), (Jakarta:2004), page.99
}

can be justified to safeguard the public interest.

g. Journalists and professional media should be was responsible to the community and also to the owners of capital or investor and the market. ${ }^{11}$

The social responsibility theory requires that media cannot only free expression and search for truth freely, but there must be social responsibility. Because what is conveyed through the media always has the effect or impact on society, thus the concept of media responsibility or the press is always bound up with the social word which seeks to show the concept of a media obligation to serve the public interest.

The act of journalism contains idealism and ideology, as an effort to provide information to empower people to run the press working in the broadcasting, must pay attention to news value, among others actuality, importance and has large impact on the public interest. $^{12}$

11 Denis McQuail, Teori Komunikasi Massa Suatu Pengantar (terjemahan), Jakarta, 1996, page.117

12 Amir Effendi Siregar, Jurnal media kasus Silet: Kemenangan bagi Publik,KPI 2012, page 12 
Bill Kovach and Tom Rosentiel ${ }^{13}$ formulated that the main purpose of journalism is to provide the needed information by public so that they can live in freedom and self-regulate. In running the task, there are 9 (nine) elements:

a) The main obligations of journalism are truth.

b) The first loyalty to the public/citizens.

c) Discipline in verification.

d) Maintain the independence of the keyspeaker.

e) Journalism should be applicable as the monitors of rule.

f) Journalism should provide a public forum for criticism and the support of citizens.

g) Attempting to make the important interesting and relevant

h) It must keep the comprehensive and proportional news.

i) The practitioners are allowed to follow their conscience

The Role and Function of Broadcasting Agency according to Act No. 32 of 2002

To achieve the objectives of the broadcasting, strengthen the national integration, maintain character and national identity of faith and piety,

\footnotetext{
13 Bill Kovach dan Tom Rosentiel, Sembilan Elemen Jurnalisme (Terjemahan), Yayasan Pantau, Jakarta 2006, page. 6
}

educating the nation, promote the general welfare, in order to build a society that is independent, democratic, just and prosperous, and fostering Indonesian broadcasting industry, the mandate of the broadcasting act normatively is to charge broadcast agency have a role as a media of information, education, entertainment, social control, adhesives and unifying the nation. As contained in article 4 paragraph (1) and (2) of Act No. 32 of 2002.

The Function of Broadcasting Agency as an Information Media of Education and Socialization on Law

Broadcasting agency as a media to convey or receive a variety of information, such as political information, entertainment, social and others. As an information media is a part of the function of press in idealism dimension. The information presented is a news release which has been selected from a variety of news that goes to the editorial desk, from various sources collected by the reporters in the field. Press carry a positive function in supporting the advancement of society, have a responsibility to disseminate 
information about the progress and success of the development to the community. It is expected that the community moved in the progress and success as an information media broadcasters can provide information on how the public can get to know and understand the law.

Table 1. The peoples' response on the broadcast content on television concerning the law understanding

\begin{tabular}{|c|l|c|c|c|c|c|}
\hline No & \multicolumn{1}{|c|}{ Description } & Yes & $\%$ & No & $\%$ & Total \\
\hline 1 & $\begin{array}{l}\text { Is television is } \\
\text { enough to } \\
\text { broadcast news } \\
\text { about law }\end{array}$ & 104 & $55 \%$ & 82 & $45 \%$ & 186 \\
\hline 2 & $\begin{array}{l}\text { Is viewer' legal } \\
\text { knowledge is } \\
\text { obtained of } \\
\text { television }\end{array}$ & 79 & $42 \%$ & 10 & $58 \%$ & 186 \\
\hline 3 & $\begin{array}{l}\text { Is the broadcast } \\
\text { about law } \\
\text { provides } \\
\text { enough } \\
\text { knowledge }\end{array}$ & 66 & $35 \%$ & 12 & $65 \%$ & 186 \\
\end{tabular}

Source: Primary data, 2015

The data in table 1 is trying to get an idea of how people acquire knowledge about law and how your media to perform its role as an information media, education and socialization are effective; the media is the most appropriate media to introduce the rules of the applicable law.

Learning theory refers to the process by which media consumers get the knowledge, information, and behavior. Social learning theory or social cognitive theory of mass communication according to Albert Bandura is reviewing learning process through the mass media as a challenge to the traditional learning and also said that social learning theory considers the media as major agent of socialization addition to the family, teachers, and collegues. Socially, in learning the first step is attention to an event. $^{14}$

Social Cognitive Theory provides an explanation of how behavior can be established by observation on the models displayed by the mass media. The effect of this modeling is increased through the observation of rewards and sanction imposed on the model, through the identification of the audience to the model, and by the extent to which the public have selfefficacy on behavior exemplified in the media.

Based on the table 1 shows that broadcasting agency as information media on the first question was rated by the community is still quite enough to give the portion of the news related

14 Miller. Katherine.. Communication Theories: Perspective, Processes, and Contexts. 2nd Edition. International Edition. Singapore: McGraw-Hill, 2005, page. 254 
to this law looks with acquired $55 \%$ of respondents said the news on television associated with the law in view of sufficient and respondents still perceive that viewers' knowledge associated with the law is still lacking obtained from television and that means that the function provides information related to the law to the people is still need to increased. By Social Cognitive theory, it is expected that programs on the law broadcast by broadcasters other than as a socialization media and information, it is also provides a process learning and to give effect to the knowledge and understanding and legal behavior change.

\section{Broadcasting Agency as an Education} Media

The third function of the press is as educational. This means that information or news that is disseminated through the media also serves to educate, contain the truth, educate and encourage doing a good action. The media as a media of education is a place of learning, it can be conluded as everything which can convey the message, it can stimulate thoughts, feelings, viewers so it can encourage the creation of the learning process in a person as the implementation of a process of ideas, concepts, policies, or innovation in the form of practical action and gives impact, both in the changes of knowledge, skills, values and attitudes.

The maintaining the press mentioned that the press should be able to help build self-stimulating initiatives so that the implementation of democracy Pancasila, improvement of spiritual and material life can really come realized. To provide information that educates, the press must balance the flow of information, conveying the facts on the ground objectively and selectively. Objective means the fact delivered what it is without the slightest altered by journalists and selective means only news worthy and deserve only to be conveyed while things that are not worth will not be exposed to the public.

Learning about growing public consciousness and compliance can be achieved through the broadcast media it can be look for the research results of author, based on the responses of respondents were spread by the author can be envisaged that the media is an 
effective media to increase consciousness and legal compliance of the society.

Legal consciousness is defined separately in the language that the basic word "conscious" know and understand, and as a whole is to know and understand about the law, according to Ewick and Silbey: "Legal Consciousness" refers to the ways in which people understand the law and legal institutions, namely the understandings that give meaning to the thoughts and actions of people. ${ }^{15}$

To see the extent to which the media of television is able to bring legal consciousness, the authors conducted research by distributing questionnaires to the viewers with indicators; knowing, understanding, influence attitudes and better understand and obey the rules, then on the Table below.

\footnotetext{
15 Achmad Ali, Menguak Teori Hukum (Legal Theory) dan Teori Peradilan (Judicial Prudence) Termasuk Interprestasi Undang-undang (legisprudence),Kencana,2009, page 510
}

Tabel 2. The peoples' responsen about the consciousness of law arising from the news

\begin{tabular}{|c|l|l|l|l|l|l|}
\hline $\begin{array}{l}\mathrm{N} \\
\text { o }\end{array}$ & $\begin{array}{l}\text { Descriptio } \\
\text { n }\end{array}$ & Yes & $\%$ & No & $\%$ & Total \\
\hline 1 & $\begin{array}{l}\text { Is the } \\
\text { television } \\
\text { news } \\
\text { make } \\
\text { more } \\
\text { conscious } \\
\text { of the rule }\end{array}$ & 142 & $76 \%$ & 44 & $24 \%$ & 186 \\
\hline 2 & $\begin{array}{l}\text { Is the } \\
\text { news on } \\
\text { television } \\
\text { make a } \\
\text { full } \\
\text { understan } \\
\text { ding of } \\
\text { the rules }\end{array}$ & 121 & $65 \%$ & 65 & $35 \%$ & \\
\hline 3 & $\begin{array}{l}\text { Is the } \\
\text { news on } \\
\text { television } \\
\text { can affect } \\
\text { his/her } \\
\text { attitude in } \\
\text { assessing } \\
\text { the law }\end{array}$ & 116 & $62 \%$ & 70 & $38 \%$ & \\
\hline 4 & $\begin{array}{l}\text { The news } \\
\text { on } \\
\text { television } \\
\text { to make } \\
\text { more } \\
\text { understan } \\
\text { ding and } \\
\text { also } \\
\text { complianc } \\
\text { e to the } \\
\text { rule }\end{array}$ & 118 & $63 \%$ & 68 & $37 \%$ & \\
\hline
\end{tabular}

Source: Primary ata, 2015

Table 2 illustrates that the television media is a very effective media of giving the legal consciousness of people that through a broadcast program on the television, the knowledge and understanding and assessment of the law created. In view of Ewick and Silbey that, "conceive it legal consciousness is neither attitude nor epiphenomenon, but cultural practice. Legal consciousness as cultural practice attempts to integrate human agency and structural 
constraint by showing how individual understandings and social interactions aggregate to partly shape institutions (agency) while institutions and larger social structures provide the foundations for and constraints on individual understanding and social interaction". ${ }^{16}$ Legal consciousness is not just an attitude but how to make legal consciousness as a cultural practice.

The theory of cultural norms by Melvin DeFleur said essentially the mass media through its presentation are selective and suppression - its emphasis on the specific themes are able to create a great impression on the audience where the cultural norms of the topic by weight, is formed by the certain ways where individual behavior usually guided by the cultural norms on a certain thing, ${ }^{17}$ then the communication media will indirectly may affect the behavior of people.

Achmad Ali stated that knowing the presence of three types of compliance, then it cannot simply use

${ }^{16}$ Silbey, Susan S .Making a Place for a Cultural Analysis of Law. Law \& Social Inquiry, 1992, page. 38.

17 Tommy Suprapto, Pengantar Teori dan Manajemen Komunikasi, MedPress, Yogyakarta, 2009, page.54 the measure compliance with a legal rule or law as evidence of ineffectiveness of the rule, but most whether there should be differences in the quality of its effectiveness. The more citizens who abide by a rule of law or the law simply by obedience that is "compliance" or "identification" only, meaning the quality of its effectiveness is still low; on the contrary more and more obedience or compliance "internalization", the higher the quality of the effectiveness of the rule of law. ${ }^{18}$

The theory about media saying that broadcasting agency as a mass communication media is able to create culture norm, then in table 3 below attempts to get an idea of how to foster the rule of law through broadcasting programs about the law in the broadcast media.

\footnotetext{
${ }^{18}$ Ibid page. 349
} 
Table 3. The peoples' response of legal compliance that arising from broadcast

\begin{tabular}{|c|c|c|c|c|c|c|}
\hline No & Description & Yes & $\%$ & No & $\%$ & Total \\
\hline 1 & $\begin{array}{l}\text { What the } \\
\text { compliante to } \\
\text { the rule or a } \\
\text { law due to } \\
\text { the news on } \\
\text { television } \\
\text { because of } \\
\text { severe } \\
\text { sanctions } \\
\text { against rule }\end{array}$ & 94 & $51 \%$ & 92 & $49 \%$ & 186 \\
\hline 2 & $\begin{array}{l}\text { What the } \\
\text { compliance } \\
\text { to the rule } \\
\text { due to the } \\
\text { individual } \\
\text { pressure or } \\
\text { they do not } \\
\text { want to be } \\
\text { seen as } \\
\text { people who } \\
\text { like to break } \\
\text { the rules }\end{array}$ & 50 & $27 \%$ & 136 & $73 \%$ & 186 \\
\hline 3 & $\begin{array}{l}\text { What the } \\
\text { compliance } \\
\text { to the rule or } \\
\text { a law due to } \\
\text { better } \\
\text { understand } \\
\text { moral } \\
\text { reasons }\end{array}$ & 127 & $68 \%$ & 59 & $32 \%$ & 186 \\
\hline
\end{tabular}

Source: Primary data, 2015

The results are concluded that the broadcast of law on television in general resulted the legal compliance of society with the high effectiveness of the rule, this is seen with the results obtained from the respondents was $68 \%$, in the theory of Herbert $\mathrm{C}$. Kelman on legal compliance showed that the broadcast media is able to give an impact of legal compliance that are Internalization for its viewer, this is a highest level of quality of legal compliance than the legal compliance that are compliance and identification, with more influence on the viewer about the impact of broadcasting it to the concept of media/broadcasting agency as agents of change or culture norms were able to build a rule of law by using an indicator that the media has the ability to form public opinion as well as the direct effect of the news or broadcasts to the individual and also able to influence the culture, the collective knowledge, norms and values of a society will thus be able to build a law-abiding of peoples through the broadcast content and programs of broadcast quality.

The influence of the broadcast in mass media on the formation of public opinion so that it can affect the effectiveness of the law and said A.V. Dicey cited by Achmad Ali, one of the five main things that should be considered in relation between law and public opinion is that the formation of public opinion against the law, directly or indirectly influenced by the values, trust and confidence, sentiment and prejudice adopted by the peoples. ${ }^{19}$

Recognizing the influence of the press or broadcast media in shaping public opinion, including opinions

19 Ahmad Ali dan Wiwie Heryani, Menjelajah kajian Empiris Terhadap Hukum, Kencana Predana Group, Jakarta, 2012, page. 147 
about the law could have been quite large in addition to having a positive impact but also can also negative impact. Thus, it is important in any use of the function of broadcastig should be used in order to introduce the values to build character of the nation. As contained in the seven principles of accountability of social media, one of them that society and public, based on the principles of the former, have the right to expect a standard of high achievement and intervention can be justified to guarantee the public interest and it is important what was presented the broadcast media is a result the work accomplished by establishing standards or high professionalism.

The Function of Press as an Entertainment Media

In Act No. 40 of 1999 article 3, paragraph 1 stated that one of the functions of press is as entertainment media. Entertainment provided the press should not come out of the corridors should and should not be exceeded. Entertainment that educating or neutral obviously allowed but that violates religious values, morality, a person's rights, or the rule is not allowed. Entertainment given to the people can bring a negative impact, especially when the entertainment was forbidden contain elements such as pornography and so should be avoided.

Act No. 32 of 2002 regulates the provisions of any content provided by Article 36, as follows:

1. The content of broadcast shall contain the information, education, entertainment, and benefits for the formation of intellect, character, morality, progress, strength of the nation, maintaining unity and integrity, as well as practice the values of religion and culture of Indonesia.

2. The content of broadcast, which was organized by the Agency for Private Broadcasting and Public Broadcasting, must contain at least $60 \%$ (sixty percent) of the program is local.

3. The content of broadcast must provide protection and empowerment to the audiences, such as children, young and adolescents, by broadcasting the program in a timely manner, and broadcasting agency shall gives and/or mention the classification of 
audience in accordance with the broadcast content.

4. The content of broadcast must be maintained neutrality and should not put the interests of certain groups.

5. The contents of the broadcast is prohibited:

a) Defamatory, misleading and/or false;

b) Highlighting elements of violence, obscene, gambling, the misuse of narcotics and drugs; or

c) Intervene race, religion, and intergroup.

d) The contents of broadcast is prohibited deride, humiliate, harass and/or ignore religious values, Indonesian human dignity, or to damage international relations.

In Article 57 of Act No. 32 of 2002, violations of these provisions be punished for 5 (five) years of imprisonment and a fine of as much Rp. 10.000.000.000,00 (ten billion rupiah). So, based on the provisions of the chapter provides a rule of order to all broadcasters that every program and broadcast content in the activities of broadcasting must contain elements of religious values and culture of Indonesia that provides information, education, entertainment and benefits to the formation of intellect, character, moral, progress, strength of the nation, and can maintain the unity of the nation. The sanctions contained in article 57 of Act No. 32 of 2002 is given relate dto the violation of the rules of order in these provision.

Given broadcasting has a great influence in shaping opinions, attitudes and behavior of the audience, then the organizer of broadcasting must be responsible in maintaining moral values, ethics, culture, personality and unity of the nation and the existence of broadcasters play a role in the formation of political behavior, social, and economic every strata of society. 
Table 4. The peoples' response to the impact of broadcast on television

\begin{tabular}{|c|c|c|c|c|c|c|}
\hline No & $\begin{array}{c}\text { Descriptio } \\
n\end{array}$ & Yes & $\%$ & No & $\%$ & Total \\
\hline 1 & $\begin{array}{l}\text { What the } \\
\text { broadcast } \\
\text { on an } \\
\text { event has } \\
\text { an impact } \\
\text { of strong } \\
\text { understand } \\
\text { ing } \\
\text { (causing } \\
\text { anxiety or } \\
\text { fear) }\end{array}$ & 104 & $\begin{array}{l}55 \\
\%\end{array}$ & 82 & $\begin{array}{l}45 \\
\%\end{array}$ & 186 \\
\hline 2 & $\begin{array}{l}\text { Opinions } \\
\text { about the } \\
\text { broadcast } \\
\text { of violence } \\
\text { that may } \\
\text { affect } \\
\text { attitudes of } \\
\text { others }\end{array}$ & 132 & $\begin{array}{l}70 \\
\%\end{array}$ & 54 & $\begin{array}{l}30 \\
\%\end{array}$ & 186 \\
\hline 3 & $\begin{array}{l}\text { What the } \\
\text { broadcast } \\
\text { on } \\
\text { television } \\
\text { about } \\
\text { violance is } \\
\text { quite more }\end{array}$ & 143 & $\begin{array}{l}76 \\
\%\end{array}$ & 43 & $\begin{array}{l}24 \\
\%\end{array}$ & 186 \\
\hline 4 & $\begin{array}{l}\text { The } \\
\text { broadcast } \\
\text { about laws } \\
\text { of the } \\
\text { program is } \\
\text { favored }\end{array}$ & 103 & $\begin{array}{l}55 \\
\%\end{array}$ & 83 & $\begin{array}{l}45 \\
\%\end{array}$ & 186 \\
\hline
\end{tabular}

Source: Primary data, 2015

Based on table 4 , it is seen how the broadcast or news related to the laws and violence has an influence and impact on the audience or the public. Because the importance of media as a media of forming an impression today can be said to be more prominent (Gill Oberlander and Austin, 2006; Gosling Gaddis and Vazire, 2007). ${ }^{20}$

The concept of mass communication is said to be an institution that gave information in the

${ }^{20}$ Charles R, Berger, Michael E. Roloff, DavId R.Roskos, Hanbook Ilmu Komunikasi,(terjemahan), Nusa Media, Bandung 2014, page 379 form of messages, news, events or products which affect and reflect the culture of a society. The mass media are able to create in the public organize, determine the issues, give equality framework. ${ }^{21}$

The media as a means to influence the public is very precise used as a means or a tool to socialize the law in what way the packaging of each program is packaged in such a way in order to attract viewers or those better watch it, as a function of healthy entertainment is intended in creating and presenting programs which lawnuance should be able to give the impression to the public to arouse the attitudes and the way people view the law. In a theory of media saying that the media is able to create a culture norms that means through the function of media is not only as a transmitter of information to socialize to the law to the public but also how the broadcast media can have the effect of influencing the behavior and attitude of law-abiding.

\footnotetext{
21 H.M Burhan Bungin, Sosiologi Komunikasi: Teori, Pardigma dan Diskusrsus Teknologi Komunikasi di Masyarakat, Kencana, Jakarta 2011, page. 262
} 
The purpose of broadcasting in Article 3; how broadcasting was organized with the aim to strengthen national integration, maintain the character and national identity of faith and piety, educating the nation, promote the general welfare, in order to build a society that is independent, democratic, just and prosperous, and fostering Indonesian broadcasting industry. $^{22}$

Through the broadcast media is certainly one of them is expected to change the concept of public about the law. According to Satjipto Rahardjo; change the concept of the public about the law, based on empirical data was constructed theoretical concept that the law is not just a regulatory affairs ( $a$ business of rule), but also behavior (matter of behavior). ${ }^{23}$ And values determine a persons' behavior in the community. It is said when the law is needed as a means for social change, the first questioned is which way it is directed or desired changes would have also thought about the system of values which were at one time to be a

22 UU No 32 of 2002

23 Satjipto Rahardjo, Penegakan Hukum Progresif, PT Kompas Media Nusantara, Jakarta 2010, page 257 framework to regulate. In Indonesia, the selection can be done to deal with a plurality of values that exist and the factor of values lived in the community is a determinant in which the law can be a social change. ${ }^{24}$

\section{CONCLUSIONS}

Broadcasting agency as media is not only has an effect directly to the person, but also affects the culture, the collective knowledge, norms and values of a society. The mass media has presented a set of image, ideas, and evaluation of where the audience can choose and make a reference for their behavior, then the role of broadcasting agency in an effort to build the legal compliance to the peoples through actiities providing information and legal clarification in order to provide an understanding to the society about teh effective media communication so that the objectives expected to be achieved. With the attachment of broadcasting agency accountability, in running their functions and roles, the broadcasting agency as a communication media is the most important

24 Satjipto Rahardjo, Hukum dan Perubahan Sosial, Cet ketiga, Genta Publishing, Yogyakarta, 2009 page. 143 
means as a bridge of peoples' understanding as a law-abiding society that is able to change the behavior of individuals in the community under the conscious level in accordance with the purpose of internalized law in individuals' behavior.

The purpose of broadcasting is strengthen the national integration, maintain the character and national identity of faith and piety, educating the nation, then the mandate of broadcasting act is normatively charge the broadcastign agency a role as a media of information, education, entertainment, social control, strengthen and unifying the nation, it is necessary to increase the content of quality broadcast program and attractive containing about understanding and knowledge about the law that is better for the peoples so as to increase consciousness and legal compliance of society.

\section{BIBLIOGRAPHY}

Ahmad Ali dan Wiwie Heryani, (2012), Menjelajah kajian Empiris Terhadap Hukum, Kencana Predana Group, Jakarta,
Achmad Ali, (2009), Menguak Teori Hukum (Legal Theory) dan Teori Peradilan (Judicial Prudence) Termasuk Interprestasi Undangundang (legisprudence),Kencana, Jakarta.

Ade Armando, (2011), Televisi Jakarta diatas Indonesia, Penerbit Bentang, Yogyakarta,

Amir Effendi Siregar, (2012), Jurnal media kasus Silet: Kemenangan bagi Publik, KPI, Jakarta.

Asep Saefullah Muhtadi, 1999, Jurnalistik Pendekatan Teori dan Praktek, Jakarta.

Bill Kovach dan Tom Rosentiel, (2006), Sembilan Elemen Jurnalisme (Terjemahan), Yayasan Pantau, Jakarta

Charles R, Berger, Michael E. Roloff, DavId R.Roskos, (2014), Hanbook Ilmu Komunikasi,(terjemahan), Nusa Media, Bandung

Judhariksawan, (2010) Hukum Penyiaran, Cet ke I, PT Rajagrafindo Persada, Jakarta,

McQuail Dennis, (2005) Mass Commucation theory (fifth edition). Sage Publications : London. 
Miller. Katherine.

Communication

Theories:

Perspective, Processes, and

Contexts. 2nd Edition.

International Edition. Singapore:

McGraw-Hill

H.M Burhan Bungin, (2011) Sosiologi

Komunikasi: Teori, Pardigma

dan Diskusrsus Teknologi

Komunikasi di Masyarakat,

Kencana, Jakarta.

S. Satya Dharma, dkk.,( 2003)

Malpraktek Pers Indonesia, dari

Somasi B.J. Habibie ke Tuntutan

Tomy Winata, Jakarta: Asosiasi

Wartawan Muslim (AWAM)

Indonesia,.

Samsul Wahidin, (2006) Hukum Pers,

Pustaka Pelajar, Yogyakarta,.

Satjipto Rahardjo, (2010) Penegakan

Hukum Progresif, PT Kompas

Media Nusantara, Jakarta

Silbey, Susan S . 1992, Making a Place

for a Cultural Analysis of Law.

Law \& Social Inquiry, 17:39-48. ,(2009) Hukum dan

Perubahan Sosial, Cet ketiga,

Genta Publishing, Yogyakarta,

Soemarno, (2004) Perbandingan

Sistem Komunikasi, Jakarta,
Tommy Suprapto, (2009) Pengantar Teori dan Manajemen Komunikasi, MedPress, Yogyakarta,

William L. Rivers, (2004) Media Massa \& Masyarakat Modern (terjemahan), Jakarta,.

\section{Jurnal}

Agus Sudibyo, 2004, Jurnal Ekonomi Politik Media Penyiaran, LKiS Yogyakarta,

Media wacth Jurnal Pemantau Media Edisi no 67/15 Mei- 15 Juni 2008

Media wacth Jurnal Pemantau Edisi No 68

Jurnal Media, kasus Silet Kemenangan bagi Pubik tahun 2012

PenyiaranKita Edisi Juli - Agustus 2015

PenyiaranKita Edisi September Desember 2015

Zulkarnain Ibrahim Pengaturan dan Penegakan Hukum Pengupahan dalam Sistem Hukum Ketenagakerjaan, Jurnal Hukum IUS QUIA IUSTUM NO. 4 VOL. 22 OKTOBER 2015: 652 -673 . 
Peraturan Perundang-Undangan

UU NO RI No. 39 Tahun 1999

Tentang Hak Azasi Manusia

UU No. RI no. 32 Tahun 2002 Tentang penyiaran

UU No. 40 Tahun 1999 Tentang Pers
UU No 36 Tentang Telekomunikasi

Peraturan KPI No. 01/P/KPI/03/ Tahun 2012 Tentang Pedoman Perilaku Penyiaran

Peraturan KPI No 02/P/KPI/03/2012 Tentang Standar Program Siaran 